\title{
THE IMPACT OF PICTURE SERIES TOWARDS STUDENTS' ABILITY IN WRITING NARRATIVE TEXT
}

\author{
Astirini Swarastuti \\ astirini90@gmail.com \\ Akademi Bahasa Asing (ABA) \\ Dian Cipta Cendikia Bandar Lampung
}

\begin{abstract}
Penelitian ini bertujuan untuk mengetahui peranan gambar berseri sebagai media pembelajaran terhadap kemampuan menulis paragraf narasi siswa. Data dikumpulkan melalui dua test, yakni pre-test dan post-test terhadap dua kelompok siswa. Subyek penelitian adalah siswa kelas delapan (VIII) di SMP Negeri 22 Bandar Lampung yang terdiri dari 38 siswa dari kelas VIII-H sebagai kelompok kontrol dan 38 siswa dari kelas VIII-G sebagai kelompok eksperimen. Kelompok eksperimen dikenakan perlakuan dengan media gambar berseri sedangkan kelompok control tidak diberi perlakuan. Data diolah dengan menggunakan uji-t terhadap dua sample yang kenakan treatment yang berbeda. Hasil penelitian menunjukan bahwa tingkat signifikansi $1 \%=2.64,5 \%=1.99$, dan t-hitung $=$ 12.16, dapat dikatakan bahwa tingkat signifikan lebih kecil dari t-hitung. Dapat disimpulkan bahwa terdapat peranan gambar berseri terhadap kemampuan siswa dalam menulis paragraf narasi. Oleh karena itu disarankan kepada guru untuk menggunakan gambar berseri sebagai media pembelajaran paragraf narasi untuk meningkatkan kemampuan menulis siswa.
\end{abstract}

Keyword: writing, picture series, teaching

\section{Introduction}

As an International language, English is used all over the world. In order to be able to communicate with the world community, it is important for people to understand English in writing and speaking. Budiharso (2004:4) states that English is the major language which is used by people in some sectors. As we know, English is the first foreign language that taught at every high school in Indonesia. English is taught in Indonesia as a major subject from high school to university level. Some elementary schools introduce English to students as a local content. For that reason, it shows that English is important for our life. Whatever the level of the students, there are four skills that the students need to master. They are listening, speaking, reading, and writing skills.

In this era, there are so many techniques and innovations that the English teachers apply in order to make their students understand and master the skills. Many efforts have been done by teachers to make the students understand and master 
the skills. One of them is by creating interesting materials in order to attract their students to participate in class actively. In the teaching learning process, the students usually find problems in mastering the four language skills. The Indonesian governments always try to find the solution to the problems that the students have, such as revising the curriculum and creating new approaches in teaching English. Moreover, English has become a compulsory subject to be tested in the final national examination.

The writer focuses on writing because writing is a basic language skill as important as speaking, listening and reading. Many students think that writing is more complex and difficult than other a language skills because writing needs adequate grammar, vocabulary and the writing skill itself. Writing does not only focus on punctuation, vocabulary, and composition but also grammatical construction. Besides, to write well, the students must also to express their ideas in a written form. According to Gelb (1952:12), writing is a system of human intercommunication by means of visible marks. Writing is very complex and is not as easy as a spontaneous activity. Writing needs hard working in combining and arranging words and sentences. Among the four language skills taught in schools, writing is the most difficult skill to learn. It needs specialized skills that include the ability to express opinions or thoughts clearly and efficiently. These abilities can be achieved only if a learner masters some techniques of writing such as how to obtain ideas about what she or he will write, how to express ideas in a sequence of sentences, how to organize them chronologically and coherently, and how to review and then to revise the composition to be a wellcomposed writing.

The writer gave the students an example of narrative text and concluded the structures of narrative text, such as its orientation, its complication and its resolution. Unfortunately, it was not interesting enough for the students. Most of students looked bored and had hard time to understand the lesson. In fact, the students were not able to make a good writing. The reason was their poor vocabulary, difficulty in generating ideas, and lack grammar mastery. The writer felt necessary to find an interesting technique and find such innovation in teaching narrative text in order to attract the students and ease them to understand the lesson well.

One of the visual aids that can be used in writing is picture series. Munadi (2008) says that pictures make people easy to catch ideas or information conveyed in them clearly, more than if merely expressed 
verbally. When the students observe pictures, they are able to speak more, interact with their friends, and build new ideas. Pictures are often used to present situations to help students work with grammar and vocabulary. Moreover, pictures are potential to bring students to different world and can also be used to encourage students to fly in their creative imagination. The present study is aimed at improving the students' writing ability, especially in writing narrative text. Based on the frame of the theory and explanation above, the writer believes that picture series is an effective technique in teaching narrative text towards the students' writing abilities. Picture series as visual media have some functions. They are to save time, to stimulate interest, to encourage students' participation, to provide a review, and to make them easy in describing the figures, plot and place of the story. River (1981:1) says that visual aids are useful to language learner. One way to make the result of teaching English more successful is by using visual aids. Using visual aids in teaching of foreign language will get better result and the learning and teaching process will run smoothly. The students will be stimulated and helped by pictures as an illustration of the story. It will be easier for them to know the figures, places, and events of the story and ease them to write the ideas. Besides, pictures will attract students' attention to the lesson because a picture series is such an interesting innovation. So, picture series are potentially useful to encourage and ease the students to generate ideas in writing narrative text and also make them enjoy the teaching learning process.

Considering the statements above, the writer adopt picture series as an innovation which is hoped to have impact on the students' writing ability, especially in writing narrative text. The writer assumes that picture series is facilitating the students to indicate or point out the ideas of what they have to write down. So, the writer focuses on the impact of picture series towards the students' ability in writing narrative text at grade eight of SMP Negeri 22 Bandar Lampung.

\section{Methods}

This is a quantitative research in order to know whether there is impact of picture series towards the students' ability in writing narrative text at grade eighth of SMP Negeri 22 Bandar Lampung. This research was conducted using two group design. The writer took two classes. The first class (grade VIIIH) acted as experimental group and the second one (grade VIIIG) acted as control group. In experimental group, the writer used picture series in teaching narrative text in order to prove whether picture series could be used 
in improving students' ability in writing narrative text. The writer applied writing narrative text through picture series as treatment for three meetings and there was no treatment for the control group. The design was described as follows:

\section{Table 1. Experimental Group and Control Group Design}

\begin{tabular}{|c|c|c|c|c|}
\hline Groups & $\begin{array}{c}\text { Rando } \\
\text { m }\end{array}$ & $\begin{array}{c}\text { Pre- } \\
\text { Test }\end{array}$ & Treatment & $\begin{array}{c}\text { Post- } \\
\text { Test }\end{array}$ \\
\hline Experimental & $\mathrm{R}$ & $\mathrm{T}_{1}$ & $\mathrm{X}$ & $\mathrm{T}_{2}$ \\
Group & $\mathrm{R}$ & $\mathrm{T}_{3}$ & $\mathrm{O}$ & $\mathrm{T}_{4}$ \\
Control Group & & & & \\
\hline
\end{tabular}

Descriptions:

R : Random sampling

$\mathrm{T}_{1} \quad$ : Pre-test of the experimental group

$\mathrm{T}_{2} \quad$ : Post-test of the experimental group

$\mathrm{T}_{3} \quad$ : Pre-test of the control group

$\mathrm{T}_{4} \quad$ : Post-test of the control group

$\mathrm{X}$ : The treatment that the writer gives

to the experimental group

by using picture series to teach

narrative text

O : No treatment

The writer selected two classes of grade eight students at SMP Negeri 22 Bandar Lampung as sample. They are VIII$\mathrm{H}$ as experimental group which consists of 38 students and VIII-G as control group which consists of 38 students. The technique that the writer used in selecting the sample was by using random sampling technique. This sampling technique was used because there were 8 classes of the grade eighth at SMP Negeri 22 Bandar Lampung. The writer assumed that the 8 classes had the same characters so it could increase the external validity aspects. A lottery technique was used by the writer to get the samples. The instrument of the research that the writer used is written objective test. It only had one instruction which the students were asked to write a narrative story. The data was collected through pre-test and posttest for control group and experimental group.

1. Pre-Test

The pre-tests were administered for control group and experimental group. The test was written tests that asked the respondents to write down a narrative story of Malin Kundang.

2. Treatments

Treatment was designed for experimental group. The treatment was administered after pre-test. Control group was treated with traditional teaching.

3. Post-Test

Two post-tests were administered for control group and experimental group. The tests administered were written tests hat asked the respondents to write down a narrative story of Malin Kundang. 
According to Brown and Bailey (1984:39), there are some criteria to analyze the students' writing. They are as follows:

- Content

- The ideas of expression

$\circ$ The arrangement of schematic structure

- Grammar

○ The employment of grammatical form and syntactic patterns

○ The use of tenses

- Organization

○ The organization of the contents

$\circ$ The arrangement of generic structures

- Vocabulary

○ The choice of words

- Mechanic

○ Capitalization and punctuation

Table 2 Brown and Bailey (1984:39) elements of writing test

\begin{tabular}{|l|l|l|}
\hline No. & $\begin{array}{l}\text { The Elements of } \\
\text { Writing }\end{array}$ & Score \\
\hline 1. & Content & $1-30$ \\
2. & Grammar & $1-25$ \\
3. & Organization & $1-20$ \\
4. & Vocabulary & $1-20$ \\
5. & Mechanic & $1-5$ \\
\hline \multicolumn{2}{|l|}{ Total Score } & 100 \\
\hline
\end{tabular}

According to Jacobs et al. (1981) in Weigle (2001), the scoring procedures for writing assessment are rated on five aspects: content, organization, vocabulary, language use, and mechanic. From the

scoring systems of writing mentioned above, the writer assumes that Brown and Bailey (1984:39) scoring system is appropriate in assessing the grade eight of Junior High School students' writing. The writer assesses students' writing by using the scoring procedures for writing assessment as in table 2 . The grade of students' achievement assesses by using students' achievement criteria as in table 3.

Table 3. The Table of Student's Achievement

\begin{tabular}{|c|c|}
\hline $\begin{array}{c}\text { CRITERIA OF } \\
\text { MASTERY }\end{array}$ & GRADE \\
\hline $91-100$ & Excellent \\
$81-90$ & Very Good \\
$71-80$ & Good \\
$61-70$ & Fair \\
$51-60$ & Poor \\
less than 50 & Very Poor \\
\hline
\end{tabular}

The formula of t-Test for two group design is presented as follows:

$$
t=\frac{\mathrm{Mx}-\mathrm{My}}{\sqrt{\left(\frac{\sum \mathrm{x}^{2}+\sum \mathrm{y}^{2}}{\mathrm{Nx}+\mathrm{Ny}-2)\left(\frac{1}{\mathrm{Nx}}+\frac{1}{\mathrm{Ny}}\right)}\right.}}
$$

$\mathrm{df}=\mathrm{Nx}+\mathrm{Ny}-2$

Descriptions:

$\mathrm{Mx}=$ Mean of Control Group

My = Mean of Experimental Group

$\mathrm{x}=$ Deviation of $\mathrm{x}_{1}$ and $\mathrm{x}_{2}$

$\mathrm{y}=$ Deviation of $\mathrm{y}_{1}$ and $\mathrm{y}_{2}$

$\mathrm{N}=$ Total number of subject

\section{Result and Discussion}


This research was conducted at grade eight students of SMP Negeri Bandar Lampung. The objective of the research was to find out if there is impact of picture series towards the students' ability in writing narrative text at grade eight of SMP Negeri 22 Bandar Lampung. The scores of pre-test and post-test of experimental group (grade $8 \mathrm{H})$ are presented in table 5.

Table 4. The Result of Pre-Test and Post-Test of Experimental Group

\begin{tabular}{|c|c|c|c|}
\hline No. & Subjects & Pre-Test & Post-Test \\
\hline 1. & Adam Firmansyah & 80 & 90 \\
\hline 2. & Afdi Fauzul Bahar & 65 & 75 \\
\hline 3. & Agtashah Fahar Andika & 60 & 80 \\
\hline 4. & Aliva Tukaruzzaman & 50 & 90 \\
\hline 5. & Andi Parada & 60 & 70 \\
\hline 6. & Azizah Nur Aulia & 80 & 90 \\
\hline 7. & Clifansi Remi Siswi Hati & 70 & 85 \\
\hline 8. & Dhandun Hara YudoTomo & 65 & 90 \\
\hline 9. & Dian Aprilia & 65 & 75 \\
\hline 10. & Dimaz Fathurokhman & 65 & 80 \\
\hline 11. & Erina Rosalia Irda & 70 & 85 \\
\hline 12. & Faras Seruni & 75 & 90 \\
\hline 13. & Farina Nurul Hidayah & 80 & 90 \\
\hline 14. & Friliansyah Nugraha Chandramica & 55 & 80 \\
\hline 15. & Hurul Aini & 50 & 75 \\
\hline 16. & I Made Gangga Pratama & 45 & 75 \\
\hline 17. & Kadek Mesriratih & 60 & 85 \\
\hline 18. & M. Ajie Setya & 65 & 85 \\
\hline 19. & Masayu Cahaya Atika Sari & 70 & 90 \\
\hline 20. & Melly Yuliastiyanti & 75 & 85 \\
\hline 21. & Mesy Cintia & 55 & 75 \\
\hline 22. & M. Bagus Budiman & 60 & 80 \\
\hline 23. & M. Bagus Abimanyu & 65 & 80 \\
\hline 24. & M. Ilham & 55 & 65 \\
\hline 25. & M. Jovi Asnawa & 60 & 70 \\
\hline 26. & Pungkas Tri Hapsoro & 70 & 85 \\
\hline 27. & Rafa Aina Cecillia & 75 & 90 \\
\hline 28. & Rani Mutia Sari & 60 & 90 \\
\hline 29. & Rega Adi Pratama & 65 & 90 \\
\hline 30. & Reinata Rhamadanti & 55 & 80 \\
\hline 31. & Reza Jannati Utami & 75 & 85 \\
\hline 32. & Risman Hanafi & 80 & 90 \\
\hline 33. & Rivaldi Olvando & 80 & 85 \\
\hline 34. & Sari Laili Haz Hutagalung & 65 & 75 \\
\hline
\end{tabular}




\begin{tabular}{|c|l|c|c|}
\hline No. & Subjects & Pre-Test & Post-Test \\
\hline 35. & Shella Permata Sari & 65 & 80 \\
\hline 36. & Syarrifah AlvitaraIdini & 70 & 85 \\
\hline 37. & Veby Rienedima & 75 & 80 \\
\hline 38. & Wellica Gustia Putri & 70 & 85 \\
\hline \multicolumn{2}{|r|}{ Total } & $\mathbf{2 5 0 5}$ & $\mathbf{3 1 2 5}$ \\
\hline & Average & $\mathbf{6 5 . 9 2}$ & $\mathbf{8 2 . 2 4}$ \\
\hline
\end{tabular}

The scores of pre-test and post-test of control group (grade $8 \mathrm{H}$ ) is presented in table 5 .

Table 5. The Result of Pre-Test and Post-Test of Control Group

\begin{tabular}{|c|c|c|c|}
\hline No. & Subjects & Pre-Test & Post-Test \\
\hline 1. & Aidil Fitra A & 55 & 60 \\
\hline 2. & Aisyah Jessica L & 45 & 40 \\
\hline 3. & Annisa Rabihan & 60 & 65 \\
\hline 4. & Ayu Karina & 35 & 55 \\
\hline 5. & Azza Fitria & 50 & 55 \\
\hline 6. & Bayu Candrakanta & 55 & 60 \\
\hline 7. & Deliana Hamida & 60 & 60 \\
\hline 8. & Desi Susanti & 60 & 60 \\
\hline 9. & Dinda Fatriani & 50 & 60 \\
\hline 10. & Ella Septiana & 60 & 60 \\
\hline 11. & Fenna Nabilla & 60 & 60 \\
\hline 12. & Ichsan Erydian & 70 & 75 \\
\hline 13. & Irfan Agustian & 70 & 70 \\
\hline 14. & Jenika Dini Putri & 80 & 80 \\
\hline 15. & Kurnia Cahya & 45 & 50 \\
\hline 16. & M. Taqiuddin & 60 & 65 \\
\hline 17. & Meuthia Savlikha & 55 & 60 \\
\hline 18. & M. Aditya & 65 & 65 \\
\hline 19. & M. Nasyeh & 50 & 55 \\
\hline 20. & M. Rizky Fazar & 70 & 70 \\
\hline 21. & Mulki Aja Perdana & 60 & 65 \\
\hline 22. & Nindy Mareshka & 50 & 60 \\
\hline 23. & Oky Afrian & 60 & 65 \\
\hline 24. & Pandu Dewangga & 65 & 65 \\
\hline 25. & Rahmi Kinasih & 60 & 65 \\
\hline 26. & Raihan Tino & 50 & 55 \\
\hline 27. & Rizki Wahyu Ningsih & 70 & 70 \\
\hline 28. & Septiawati Agustina & 50 & 55 \\
\hline 29. & Sri Pangestu Safra & 60 & 60 \\
\hline 30. & Sultan Malik Ibrahim & 60 & 65 \\
\hline 31. & Swarna Darma Utama & 65 & 65 \\
\hline 32. & Teni Kartika Putri & 70 & 70 \\
\hline
\end{tabular}




\begin{tabular}{|c|l|c|c|}
\hline No. & \multicolumn{1}{|c|}{ Subjects } & Pre-Test & Post-Test \\
\hline 33. & Umairi Alyamin & 60 & 65 \\
\hline 34. & Verly Rofiull Aziz & 60 & 65 \\
\hline 35. & Wika Rahayu & 70 & 65 \\
\hline 36. & Wiranto Irawan Palam & 65 & 60 \\
\hline 37. & Tania Ayu & 60 & 65 \\
\hline 38. & Destia Happyana & 70 & 70 \\
\hline \multicolumn{2}{|c|}{ Total } & $\mathbf{2 2 6 0}$ & $\mathbf{2 3 8 0}$ \\
\hline Average & $\mathbf{5 9 . 4 7}$ & $\mathbf{6 2 . 6 3}$ \\
\hline
\end{tabular}

Table 6. Calculation Scores of Control Group

\begin{tabular}{|c|c|c|c|c|}
\hline \multicolumn{5}{|c|}{ Control Group } \\
\hline Subject & $\begin{array}{c}\text { Pre-Test } \\
\left(\mathrm{X}_{1}\right)\end{array}$ & $\begin{array}{c}\text { Post-Test } \\
\left(\mathrm{X}_{2}\right)\end{array}$ & $\mathrm{X}$ & $\mathrm{X}^{2}$ \\
\hline 1 & 55 & 60 & 5 & 25 \\
\hline 2 & 45 & 40 & 5 & 25 \\
\hline 3 & 60 & 65 & 5 & 25 \\
\hline 4 & 35 & 55 & 20 & 400 \\
\hline 5 & 50 & 55 & 5 & 25 \\
\hline 6 & 55 & 60 & 5 & 25 \\
\hline 7 & 60 & 60 & 0 & 0 \\
\hline 8 & 60 & 60 & 0 & 0 \\
\hline 9 & 50 & 60 & 10 & 100 \\
\hline 10 & 60 & 60 & 0 & 0 \\
\hline 11 & 60 & 60 & 0 & 0 \\
\hline 12 & 70 & 75 & 5 & 25 \\
\hline 13 & 70 & 70 & 0 & 0 \\
\hline 14 & 80 & 80 & 0 & 0 \\
\hline 15 & 45 & 50 & 5 & 25 \\
\hline 16 & 60 & 65 & 5 & 25 \\
\hline 17 & 55 & 60 & 5 & 25 \\
\hline 18 & 65 & 65 & 0 & 0 \\
\hline 19 & 50 & 55 & 5 & 25 \\
\hline 20 & 70 & 70 & 0 & 0 \\
\hline 21 & 60 & 65 & 5 & 25 \\
\hline 22 & 50 & 60 & 10 & 100 \\
\hline 23 & 60 & 65 & 5 & 25 \\
\hline 24 & 65 & 65 & 0 & 0 \\
\hline 25 & 60 & 65 & 5 & 25 \\
\hline 26 & 50 & 55 & 5 & 25 \\
\hline 27 & 70 & 70 & 0 & 0 \\
\hline 28 & 50 & 55 & 5 & 25 \\
\hline 29 & 60 & 60 & 0 & 0 \\
\hline 30 & 60 & 65 & 5 & 25 \\
\hline 31 & 65 & 65 & 0 & 0 \\
\hline 32 & 70 & 70 & 0 & 0 \\
\hline 33 & 60 & 65 & 5 & 25 \\
\hline
\end{tabular}




\begin{tabular}{|c|c|c|c|c|}
\hline \multicolumn{5}{|c|}{ Control Group } \\
\hline Subject & $\begin{array}{c}\text { Pre-Test } \\
\left(\mathrm{X}_{1}\right)\end{array}$ & $\begin{array}{c}\text { Post-Test } \\
\left(\mathrm{X}_{2}\right)\end{array}$ & $\mathrm{X}$ & $\mathrm{X}^{2}$ \\
\hline 34 & 60 & 65 & 5 & 25 \\
\hline 35 & 70 & 65 & -5 & 25 \\
\hline 36 & 65 & 60 & -5 & 25 \\
\hline 37 & 60 & 65 & 5 & 25 \\
\hline 38 & 70 & 70 & 0 & 0 \\
\hline $\mathbf{N = 3 8}$ & $\sum \mathbf{X}_{\mathbf{1}=2260}$ & $\sum \mathbf{X}_{\mathbf{2}=2380}$ & $\Sigma \mathbf{X = 1 2 5}$ & $\Sigma \mathbf{X}^{\mathbf{2 =}} \mathbf{1 1 2 5}$ \\
\hline
\end{tabular}

Table 7. Calculation Scores of Experimental Group

\begin{tabular}{|c|c|c|c|c|}
\hline \multicolumn{5}{|c|}{ Experimental Group } \\
\hline Subject & $\begin{array}{c}\text { Pre-Test } \\
\left(\mathrm{Y}_{1}\right)\end{array}$ & $\begin{array}{c}\text { Post-Test } \\
\left(\mathrm{Y}_{2}\right)\end{array}$ & $\mathrm{Y}$ & $\mathrm{Y}^{2}$ \\
\hline 1 & 80 & 90 & 10 & 100 \\
\hline 2 & 65 & 75 & 10 & 100 \\
\hline 3 & 60 & 80 & 20 & 400 \\
\hline 4 & 50 & 90 & 40 & 1600 \\
\hline 5 & 60 & 70 & 10 & 100 \\
\hline 6 & 80 & 90 & 10 & 100 \\
\hline 7 & 70 & 85 & 15 & 225 \\
\hline 8 & 65 & 90 & 15 & 225 \\
\hline 9 & 65 & 75 & 10 & 100 \\
\hline 10 & 65 & 80 & 15 & 225 \\
\hline 11 & 70 & 85 & 15 & 225 \\
\hline 12 & 75 & 90 & 15 & 225 \\
\hline 13 & 80 & 90 & 10 & 100 \\
\hline 14 & 55 & 80 & 25 & 625 \\
\hline 15 & 50 & 75 & 25 & 625 \\
\hline 16 & 45 & 75 & 30 & 900 \\
\hline 17 & 60 & 85 & 20 & 400 \\
\hline 18 & 65 & 85 & 20 & 400 \\
\hline 19 & 70 & 90 & 20 & 400 \\
\hline 20 & 75 & 85 & 10 & 100 \\
\hline 21 & 55 & 75 & 20 & 400 \\
\hline 22 & 60 & 80 & 20 & 400 \\
\hline 23 & 65 & 80 & 15 & 225 \\
\hline 24 & 55 & 65 & 10 & 100 \\
\hline 25 & 60 & 70 & 10 & 100 \\
\hline 26 & 70 & 85 & 15 & 225 \\
\hline 27 & 75 & 90 & 15 & 225 \\
\hline 28 & 60 & 90 & 30 & 900 \\
\hline 29 & 65 & 90 & 25 & 625 \\
\hline 30 & 55 & 80 & 25 & 625 \\
\hline 31 & 75 & 85 & 10 & 100 \\
\hline 32 & 80 & 90 & 10 & 100 \\
\hline 33 & 80 & 85 & 5 & 25 \\
\hline
\end{tabular}




\begin{tabular}{|c|c|c|c|c|}
\hline \multicolumn{5}{|c|}{ Experimental Group } \\
\hline Subject & $\begin{array}{c}\text { Pre-Test } \\
\left(\mathrm{Y}_{1}\right)\end{array}$ & $\begin{array}{c}\text { Post-Test } \\
\left(\mathrm{Y}_{2}\right)\end{array}$ & $\mathrm{Y}$ & $\mathrm{Y}^{2}$ \\
\hline 34 & 65 & 75 & 10 & 100 \\
\hline 35 & 65 & 80 & 15 & 225 \\
\hline 36 & 70 & 85 & 15 & 225 \\
\hline 37 & 75 & 80 & 5 & 25 \\
\hline 38 & 70 & 85 & 15 & 225 \\
\hline $\mathbf{N = 3 8}$ & $\sum \mathbf{Y}_{\mathbf{1}}=\mathbf{2 5 0 5}$ & $\sum \mathbf{Y}_{\mathbf{2}}=\mathbf{3 1 2 5}$ & $\sum \mathbf{Y}=\mathbf{6 1 5}$ & $\sum \mathbf{Y}^{\mathbf{2}}=\mathbf{1 0 8 2 5}$ \\
\hline
\end{tabular}

For the experimental group, statistical deliberation of the following t-Test formula for two group designs was used:

$\mathrm{df}=\mathrm{Nx}+\mathrm{Ny}-2$

$M=\frac{\sum x}{N}$

$M=\frac{125}{38}$

$M=3.29$

$$
M=\frac{\sum y}{N}
$$$$
M=\frac{615}{38}
$$$$
M=16.18
$$

$$
\sum \mathrm{x}^{2}=\sum X^{2}-\frac{\left(\sum X\right)^{2}}{N}
$$$$
\sum x^{2}=1125-\frac{(125)^{2}}{38}
$$

$t=\frac{\mathrm{Mx}-\mathrm{My}}{\sqrt{\left(\frac{\sum \mathrm{x}^{2}+\sum \mathrm{y}^{2}}{\mathrm{Nx}+\mathrm{Ny}-2}\right)\left(\frac{1}{\mathrm{Nx}}+\frac{1}{\mathrm{Ny}}\right)}}$

$$
\tau=\frac{3.29-16.18}{\sqrt{\left(\frac{713.82+871.71}{38+38-2}\right)\left(\frac{1}{38}+\frac{1}{38}\right)}}
$$

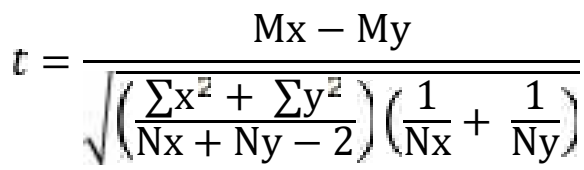

$$
\begin{aligned}
& \sum x^{2}=1125-\frac{15625}{38} \\
& \sum x^{2}=1125-411.18 \\
& \sum x^{2}=713.82
\end{aligned}
$$

$$
\begin{aligned}
& \sum \mathrm{y}^{2}=\sum Y^{2}-\frac{\left(\sum Y\right)^{2}}{N} \\
& \sum \mathrm{y}^{2}=10825-\frac{(615)^{2}}{38} \\
& \sum \mathrm{y}^{2}=10825-\frac{378225}{38} \\
& \sum \mathrm{y}^{2}=10825-9953.29 \\
& \sum \mathrm{y}^{2}=871.71
\end{aligned}
$$

$$
\begin{aligned}
& t=\frac{12.89}{\sqrt{\left(\frac{1585.53}{74}\right)\left(\frac{2}{38}\right)}} \\
& t=\frac{12.89}{\sqrt{21.43 \times\left(\frac{2}{38}\right)}}
\end{aligned}
$$




$$
\begin{aligned}
& t=\frac{12.89}{\sqrt{\frac{\overline{42.86}}{38}}} \\
& t=\frac{12.89}{\sqrt{1.13}} \\
& t=\frac{12.89}{1.06} \\
& t=12.16 \\
& \text { df }=\mathrm{Nx}+\mathrm{Ny}-2 \\
& \mathrm{df}=38+38-2 \\
& \mathrm{df}=74 \\
& \mathrm{p} 1 \%=2.64 \\
& \quad \mathrm{t}=12.16 \quad \mathrm{p} 5 \%=1.99 \\
& \therefore p<t \rightarrow \quad 2.64 / 1.99<12.16
\end{aligned}
$$

From the calculation, the t-Test value of using of picture series is significant because $p$-value is smaller than t-value. This indicated that the treatment administered by the writer has significant impact on the students' ability in writing narrative text. So, there is impact of picture series towards the students' ability in writing narrative text of grade eight at SMP Negeri 22 Bandar Lampung.

The findings indicated that the application of picture series is effective to improve students' ability in writing narrative text for the grade eight students of SMP Negeri 22 Bandar Lampung in the academic year 2012 - 2013. The form of the test item is written test. It was found that teaching writing narrative text by using series pictures better than traditional teaching under control group. It means that the students are more interested in writing narrative text by using picture series. The students` achievement which taught by using picture series was very good. The score of t-Test was 12.16 . It meant that the picture series enhanced the students`motivation to get ideas, thought, feeling, and to express them into written form.

\section{Conclusion}

The writer found that there was significant difference between the students ability of writing narrative text that were taught by using picture series and those taught without using series pictures. Those that were who were taught using picture series is better than those who were taught without using picture series. It means that picture series can help the students improve their skill in writing narrative text. The score of t-Test was 12.16. Statistically, it indicated that $\mathrm{t}$-Test value was significant because the $p$-value was smaller than t-Test value. By using picture series, the teacher can create a representative and interesting material in the teaching learning process in the classroom, because the students can express their ideas freely. Picture series usually capture past events and surely can help students to remember details about people, places, and events. In short, they can be powerful sources of text. Besides, 
the picture series is worth a thousand words because one picture can tell students something, even has sequences of story behind it. The use of picture series is quite helpful for the students to write a narrative text. This shows that teaching writing narrative text by using picture series is effective. Therefore, the application of using picture series is more effective than the application of a traditional teaching towards the students' ability in writing narrative text for grade eight students of SMP Negeri 22 Bandar Lampung.

\section{References}

Brown, et.al. 1984. An Interactive Approach to Language Pedagogy. NJ: Prentice Hall. New York.

Budiharso, Teguh. 2004. The Rhetoric Features of English and Indonesian Essays Made by EFL Undergraduate Students. PT.Erlangga. Jakarta.

Gelb, Peter. 1952. Handbook of Semiotics. Indianan University Press. Indiana. Munadi, Y. 2008. Media Pembelajaran: Sebuah Pendekatan Baru. Gaung Persada Press. Jakarta.

River, Wilga. 1978. A Practical Guide to the Teaching of English as a Second Language. University Press. Oxford.

Weigle, Sara. 2001. Assessing Writing. Cambridge University Press. Cambridge. 